\title{
PEMBENTUKAN PERATURAN DAERAH BERBASIS LINGKUNGAN DALAM RANGKA MEWUJUDKAN PRAKTIK-PRAKTIK GOOD GOVERNANCE DI DAERAH
}

\author{
Oleh: \\ I Gusti Ayu Ketut Rachmi Handayani \\ Fakultas Hukum Universitas Sebelas Maret \\ ayu_igk@yahoo.com
}

\begin{abstract}
The purpose of this research is to formulate legal drafting a model policy formulation Regional Regulation based Green Legislation in order to develop the practices of good governance in the region through strengthening the role of the executive (such as the leading sector of legal department Sector, BLH, Central Java Regional Environment and Parliament. This research is a juridical non-doctrinal, with a qualitative approach. The method will be used through the stages of: mapping the existing condition into the formulation of legal drafting which has been used, mapping of potential executive (leading sector) and the Parliament, to evaluate regulations, identify and evaluate the constraints faced in the policy formulation stage, identify opportunities and strategies and formulate a model formulation that can be developed. Sources of data used were primary and secondary data sources from the Central Java Regional Ministry of Environment, the Legal Department of Nganjuk Regency. Collection of primary data done by observation and interview and Focus Group Discussion (FGD). The collection of secondary data through literature and content analysis. Checking the validity of the data was done by using triangulation of sources. The results of research are: First, the preparation of formulations Legal Drafting regulations made by the Government in Nganjuk in accordance with Act No. 12 of 201, and Act No. 32 of 2009, but not all use the Paper of Academic regulation in the formulation so that the Legal Drafting Regional Regulation not meet the criteria of a good legal system. Second, participation has not been effective and not all regulation is preceded Academic Manuscript. Third, the constraints in the formulation of legal drafting regulations include limitations of the preparation of draft environmental preservation, the ability to assess the regulation, the ability to formulate environmental protection and management policy.
\end{abstract}

Keywords: legal drafting ,local regulation, good governance

\begin{abstract}
Abstrak
Tujuan penelitian ini adalah merumuskan model kebijakan formulasi legal drafting Peraturan Daerah (Perda) berbasis Green Legislation dalam rangka pengembangan praktik-praktik tata kelola pemerintahan yang baik di daerah melalui penguatan peran eksekutif (leading sector seperti bagian hukum, BLH, Pusat Regional Jawa KLH dan DPRD melalui strategi, mekanisme, dan pemberdayaan potensi, serta perbaikan prosedur penyusunan Perda agar memperhatikan pelestarian fungsi lingkungan hidup. Penelitian ini merupakan penelitian yuridis non-doktrinal, dengan pendekatan kualitatif. Metode yang akan dipakai melalui tahapan-tahapan berupa : pemetaan existing condition formulasi legal drafting yang selama ini digunakan, pemetaan terhadap potensi eksekutif (leading sector) dan DPRD, mengevaluasi Perda yang sudah dihasilkan selama ini (Tahun I), mengidentifikasi dan mengevaluasi kendala yang dihadapi dalam tahap formulasi kebijakan, mengidentifikasi peluang dan strategi serta merumuskan model formulasi yang dapat dikembangkan (Tahun II), menyusun pedoman dan standar prosedur operasional, memberikan pelatihan, pendampingan serta monitoring bagi eksekutif (leading sector) dan DPRD (Tahun III) Penekanan dalam rangka formulasi legal drafting yang dilakukan Pemerintah agar menghasilkan perda yang berbasis green legislation. Sumber data yang digunakan adalah sumber data primer dan sekunder dari Pusat Regional Jawa Kementerian LH, Bagian Hukum Pemkab Nganjuk. Pengumpulan data primer dilakukan dengan observasi dan wawancara. Untuk memberikan penajaman dan elaborasi data lebih lanjut dilakukan Focus Group Discussion (FGD). Pengumpulan data sekunder dilakukan melalui studi pustaka dan content analysis. Dari pembahasan hasil penelitian dihasilkan simpulan sebagai berikut. Pertama, Penyusunan formulasi Legal Drafting Perda yang dilakukan oleh Pemerintah di Kabupaten Nganjuk belum optimal karena belum sepenuhnya sesuai dengan UU No. 12 Tahun 2011 dan UU No 32 Tahun 2009, sehingga belum semua Perda menggunakan Naskah Akademik dalam formulasi Legal Drafting Perdanya . Kedua, partisipasi belum berjalan efektif dan belum semua Perda didahului Naskah Akademik. Ketiga, kendala dalam formulasi legal drafting Perda antara lain kemampuan menilai Perda, kemampuan merumuskan kebijakan perlindungan dan pengelolaan lingkungan hidup.
\end{abstract}

Kata kunci : pembentukan, perda, good governance 


\section{A. Pendahuluan}

Dalam kondisi saat ini, dimana ancaman krisis daya dukung ekosistem dan lingkungan hidup yang dihadapi Indonesia sangat nyata, maka legislasi norma hukum lingkungan di tingkat daerah baik kota, kabupaten dan provinsi sangat diperlukan seiring dengan ikhtiar di tingkat nasional maupun dunia internasional untuk memperkuat demokrasi dan negara hukum, serta tata kelola pemerintahan yang baik (good governance) (I Gusti Ayu, 2007).

Seperti dikutip dari Laurence C. Smith, "Might any of the four global forces of demography, natural resource presure, globalozation and climate change screech to a halt between now and 2050 thus ruining all of our best projections" ( Laurence C. Smith, 2011). Pemerintah Daerah dalam hal ini Eksekutif dan DPRD memegang peranan penting dan startegis dalam menghasilkan Perda-Perda yang pro terhadap lingkungan, tidak tumpang tindih dan harmoni antar perda maupun dengan peraturan perundang-undangan diatasnya. Dalam kenyataanya terdapat banyak peraturan daerah yang tidak harmonis dan tumpang tindih bahkan justru tidak melindungi fungsi lingkungan hidup (tidak berbasis pada green legislation). Bahkan banyak perda yang dibatalkan dan bertentangan dengan Undang-Undang. Hal ini dikarenakan minimnya pengetahuan dan pemahaman aparatur pemerintah daerah dan DPRD tentang legal drafting produk hukum daerah, budaya copy paste perda daerah lain, dan keterbatasan anggaran.

Di sisi lain, selain istilah ini termasuk baru, pemahaman dan kepekaan aparatur sendiri tentang green legis/ation sangat terbatas, prosedur penyusunan peraturan daerah yang tidak responsif terhadap pentingnya fungsi lingkungan di masa yang akan datang. Hal yang sangat penting adalah bahwa kondisi satu daerah dengan daerah lain berbeda sehingga akan sangat berpengaruh pada produk hukum yang dihasilkan nantinya, apakah sudah good norm dan good process serta sesuai dengan kondisi daerahnya. Oleh karena itu diperlukan formulasi untuk membangun dan menciptakan Peraturan Daerah agar berbasis pada green legislation dan tercipta praktik-praktik tata kelola pemerintahan yang baik. Tujuan jangka panjang penelitian ini adalah merumuskan model kebijakan formulasi legal drafting Peraturan Daerah (Perda) berbasis Green Legis/ation dalam rangka pengembangan praktik-praktik tata kelola pemerintahan yang baik di daerah melalui penguatan peran eksekutif (leading sector seperti bagian hukum, badan lingkungan hidup, Pusat Regional Jawa Kementrian LH) dan pimpinan serta anggota DPRD melalui strategi, mekanisme, dan pemberdayaan potensi, serta perbaikan prosedur penyusunan peraturan daerah agar memperhatikan pelestarian fungsi lingkungan hidup. Target khusus yang ingin dicapai adalah optimalisasi pemerintah daerah dan DPRD dalam rangka memformulasikan dan selanjutnya menghasilkan perda yang berbasis pada green legislation. Tidak hanya Perda di bidang lingkungan tetapi mendasari pembuatan Perda pada umumnya, sehingga tidak semata-mata membuat Perda tanpa mempedulikan keberlanjutan fungsi lingkungan terutama jika dikaitkan dengan Peningkatan Asli Daerah, tetapi Perda yang good norm dan good process serta green. Berkembangnya tuntutan yang meluas agar kebijakan-kebijakan resmi negara yang prolingkungan dapat tercermin dalam bentuk perundang-undangan yang mengingat untuk ditaati oleh semua pemangku-kepentingan (stakeholders). Law enforcement menjadi sangat penting saat ini, seperti dikatakan Steinzor (1998) ... If one agrees that varying enforcement styles are also related to cultural differences the shift in the US from traditional command and control to a more flexible system of industry self regulation could therefore be a dangerous journey...(Steinzor, 1998: 103-202). Tak terkecuali, Indonesia juga menghadapi tuntutan yang sama, yaitu perlunya disusun suatu kebijakan yang dapat dipaksakan berlakunya dalam bentuk undang-undang tersendiri yang mengatur mengenai lingkungan hidup.

Dari perspektif yuridis baik secara implisit maupun eksplisit landasan hukum untuk membuat green policy semakin menguat. Atas dorongan kesadaran yang semakin luas di seluruh dunia mengenai pentingnya upaya melindungi lingkungan hidup dari ancaman pencemaran dan perusakan, kebijakan lingkungan hidup dituangkan dalam bentuk peraturan perundang-undangan secara resmi. Dengan demikian, timbul gelombang di seluruh dunia, yaitu gelombang legalisasi atau legislasi kebijakan lingkungan hidup. Setelah ditetapkannya begitu banyak peraturan-peraturan itu tidak efektif untuk mencegah terjadinya pencemaran dan perusakan lingkungan hidup. Penelitian yang dilakukan oleh Guningham dan Grabosky "there is not just one optimal instruments to reach environmental goals at the lowest cost. The strength and weaknesses of particular institutional features of a particular legal system may play a large role in that respect" (Guningham dan Grabosky, 1998). Pasal 28H ayat (1) dan Pasal 33 ayat (4) UUD 1945 dikatakan bahwa hak untuk memperoleh lingkungan hidup yang baik dan sehat serta pelayanan kesehatan yang baik, merupakan hak asasi manusia. Oleh karena itu, UUD 1945 jelas sangat pro-lingkungan hidup, sehingga dapat disebut sebagai konstitusi hijau (green constitu- 
tion). Dengan demikian, segala kebijakan dan tindakan pemerintahan dan pembangunan haruslah tunduk kepada ketentuan mengenai hak asasi manusia atas lingkungan hidup yang baik dan sehat (I Gusti Ayu, 2005).

1. Tidak boleh ada lagi kebijakan yang tertuang dalam bentuk undang-undang ataupun peraturan di bawah undang-undang yang bertentangan dengan ketentuan konstitusional yang pro-lingkungan (I Gusti Ayu, 2006). Apalagi, Indonesia sendiri merupakan satu negara kepulauan yang sangat rentan dan rawan bencana alam. Jika lingkungan hidup tidak dilindungi, pada saatnya kerusakan alam yang terjadi justru akan merugikan bangsa Indonesia sendiri. Mulai dari ranah konstitusi (UUD 1945), UU No. 32 Tahun 2009 tentang Perlindungan dan Pengelolaan Lingkungan mengatur dengan jelas betapa pentingnya filosofi nilai-nilai hijau mutlak diperlukan dalam legal drafting Undang-Undang termasuk Peraturan Daerah. Ronald Dworkin says that it is the mark of genuine rights that, morally, politically and (in well-ordered states) constitutionally, they prevail against legislation, executive authority, and judicial decisions erroneously failing to enforce them (John Finnis,

2011) Oleh karena itu untuk mengawal kebijakan yang berwawasan lingkungan hijau, menjadi urgen menyusun pembentukan peraturan daerah (Perda) berbasis lingkungan dalam rangka mewujudkan good governance di daerah. Permasalahannya, pertama, bagaimana penyusunan Legal Drafting Peraturan Daerah yang dilakukan oleh Pemerintah Daerah (ekskutif dan DPRD) selama ini? Kedua, apakah Perda yang dihasilkan oleh eksekutif dan DPRD selama ini sudah disertai dengan Naskah Akademik dan mengikutsertakan peranserta masyarakat dalam rangka tata kelola pemerintahan yang baik di daerah? Ketiga,apa saja kendalakendala yang dihadapi eksekutif dan legislatif dalam tahap fomulasi kebijakan?

\section{B. Metode Penelitian}

Dalam penelitian ini digunakan metode yuridis empiris atau non doktrinal yang dimaksudkan sebagai usaha mendekati masalah yang diteliti dengan sifat hukum yang sesuai dengan kenyataan yang hidup dalam masyarakat. Pendekatan yang digunakan bersifat sosiologis/empiris menggunakan pendekatan non positivistik dan menggunakan analisis bersifat kualitatif (Peter Mahmud, 2006). Adapun sifat penelitiannya deskriptif developmental yang memberikan gambaran secara sistematis terhadap obyek yang akan diteliti, selanjutnya disusun model yang dapat dikembangkan untuk mengatasi problema di lapangan. Metode yang akan dipakai melalui tahapan-tahapan berupa : pemetaan existing condition formulasi legal drafting yang selama ini digunakan, pemetaan terhadap potensi eksekutif (leading sector) dan DPRD, mengevaluasi Perda yang sudah dihasilkan selama ini (Tahun I), mengidentifikasi dan mengevaluasi kendala-kendala yang dihadapi dalam tahap formulasi kebijakan, mengidentifikasi peluang dan strategi serta merumuskan model formulasi yang dapat dikembangkan (Tahun II), menyusun pedoman dan standar prosedur operasional, memberikan pelatihan, pendampingan serta monitoring bagi eksekutif (leading sector) dan anggota DPRD (Tahun III) Penekanan dalam rangka formulasi legal drafting yang dilakukan eksekutif dan DPRD agar menghasilkan perda yang berbasis green legislation. Tidak hanya Perda di bidang lingkungan tetapi mendasari pembuatan Perda pada umumnya, sehingga tidak semata-mata membuat Perda tanpa mempedulikan keberlanjutan fungsi lingkungan terutama jika dikaitkan dengan Peningkatan Asli Daerah, tetapi Perda yang good norm dan good process serta green.

Pendekatan penelitian menggunakan kualitatif. Dengan mengutip pendapat dari Denzin dan Lincoln (Lexy Moleong, 2005: 5) menjelaskan bahwa penelitian kualitatif adalah penelitian yang menggunakan latar alamiah, dengan maksud menafsirkan fenomena yang terjadi dan dilakukan dengan jalan melibatkan berbagai metode yang ada.

Penelitian ini mengambil lokasi di Kabupaten Nganjuk Jawa Timur. Dalam penelitian ini data yang diperlukan meliputi data primer maupun data sekunder. Data Primer, yaitu data yang diperoleh dari sumber data langsung atau tangan pertama, terutama yang menyangkut aspek perilaku, persepsi, sikap, dan motivasi eksekutif dan legislatif dalam penyusunan Perda. Data Sekunder, yaitu data yang bukan diusahakan sendiri pengumpulannya oleh peneliti (Marzuki, 2002: 56). Data sekunder dapat berupa majalah, laporan, hasil penelitian terdahulu, peraturan perundang-undangan serta publikasi lainnya. Sumber data sekunder meliputi bahan hukum primer, sekunder dan tersier. Instumen pengumpul data terbagi menjadi dua yakni untuk data primer menggunakan wawancara dan kuesioner. Wawancara ini dilakukan dengan indeepht interview, yaitu metode pengumpulan data melalui wawancara yang dilakukan secara mendalam kepada sumber data (W.Gulo, 2003: 119). Di samping itu untuk memberikan penajaman dan elaborasi data lebih lanjut dilakukan Focus Group Discussion (FGD) dengan melibatkan pihakpihak pemangku kepentingan. Adapun untuk data

Pembentukan Peraturan Daerah Berbasis... 68 
sekunder menggunakan Identifikasi isi dengan metode studi kepustakaan, dimana metode ini digunakan dalam rangka memperoleh data sekunder, yaitu mengumpulkan data berupa bukubuku ilmiah yang berhubungan dengan masalah yang diteliti, dokumen-dokumen, peraturan perundangan yang sesuai dan lain sebagainya dengan membaca dan mengkajinya. Dalam penelitian ini penulis menggunakan teknik analisis kualitatif, mengingat data yang terkumpul sebagian besar merupakan data kualitatif. Teknik ini tepat bagi penelitian yang menghasilkan data yang bersifat kualitatif, yaitu data yang tidak bisa dikategorikan secara statistik kualitatif. Metode kualitatif ini digunakan karena beberapa pertimbangan. Pertama, menyesuaikan metode kualitatif lebih mudah apabila berhadapan dengan kenyataan ganda. Kedua, metode ini lebih dapat menyesuaikan diri dengan banyak penajaman pengaruh bersama dan terhadap pola-pola nilai yang dihadapi (Lexy Moleong, 2005 : 153). Model analisis kualitatif yang digunakan adalah dengan cara mengkaji kinerja kepala daerah hasil pemilihan kepala daerah langsung yang menjadi obyek penelitian kemudian diproyeksikan pada standar norma-norma hukum / peraturan perundang-undangan yang berlaku ideal yang diharapkan selanjutnya ditafsirkan (diinterpresatsikan) berdasar teori (theoritical interpretation) dan untuk kemudian ditarik generalisasi sebagai rumusan yang bersifat ideal (ius constitutum).

\section{Hasil Penelitian dan Pembahasan}

1. Penyusunan Legal Drafting Peraturan Daerah yang dilakukan oleh Pemerintah Daerah (ekskutif dan DPRD).

Penyelenggaraan pemerintahan daerah dalam melaksanakan tugas, wewenang, kewajiban, dan tanggung jawabnya serta atas kuasa peraturan perungdang-undangan yang lebih tinggi dapat menetapkan kebijakan daerah yang dirumuskan antara lain dalam Peraturan Daerah. Kebijakan daerah dimaksud tidak boleh bertentangan dengan peratuan perundang-undangan yang lebih tinggi dan kepentingan umum serta peraturan daerah lain. Penyusunan formulasi legal drafting Perda yang saat ini dilakukan dapat melalui eksekutif dan legislatif.

Sebagai suatu manajemen proses pembentukan peraturan daerah dilakukan dengan:

\section{a. Perencanaan.}

Perencanaan penyusunan Peraturan Daerah dilakukan dalam suatu Program Legislasi Daerah. Program legislasi daerah merupakan landasan yuridis bagi dibentuknya mekanisme koordinasi baik antara instansi di lingkungan Pemerintah Daerah dalam pemyusunan Peraturan Daerah maupun antara Pemerintah daerah dan Dewan Perwakilan Rakyat Daerah, Khusus untuk Dewan Perwakilan Rakyat Daerah pentingnya kedudukan alat perlengkapan Dewan seperti Badan Legislasi DPRD sangat penting, karena badan inilah yang diharapkan dapat menumpang aspirasi baik yang berasal dari komisi-komisi, fraksi-fraksi, maupun dari masyarakat berkaitan dengan masalah peraturan daerah.

\section{b. Persiapan Pembentukan Perda.}

Rancangan peraturan daerah dapat berasal dari dewan perwakilan rakyat daerah (DPRD) Provinsi, DPRD Kabupaten/DPRD Kota) atau berasal dari gubernur atau Bupati/Walikota, masingmasing sebagai kepala pemerintahan daerah provinsi, kabupaten atau kota. Rancangan peraturan daerah yang berasal dari inisiatif DPRD dapat disampaikan oleh nggota, komisi, gabungan komisi atau alat kelengkapan dewan perwakilan rakyat yang khusus menangani bidang legislasi. Selanjutnya Raperda inisiatif DPRD ini disampaikan oleh pimpinan dewan perwakilan rakyat daerah kepada gubernur atau bupati/walikota. Agar rancangan peraturan daerah diketahui oleh khalayak ramai dan masyarakat dapat memberikan masukan sehubungan dengan ketentuan Pasal 139 ayat (1) Rancangan UndangUndang tentang Pemerintahan Daerah bahwa masyarakat berhak memberikan masukan lisan atau tulisan dalam rangka penyiapan atau pembahasan Raperda, maka rancangan daerah yang berasal dari DPRD harus disebarluaskan yang pelaksanaannya dilakukan oleh secretariat dewan perwakilan rakyat daerah. Salah satu wujud nyata berupa peran DPRD dalam melaksanakan fungsi legislasi sebagaimana ditentukan dalam Pasal 140 ayat (2) Rancangan UndangUndang tentang Peraturan Daerah bahwa apabila dalam satu masa sidang, gubernur atau bupati/walikota dan DPRD menyampaikan Raperda mengenai materi yang sama, maka yang dibahas adalah Raperda yang disampaikan oleh DPRD, sedangkan Raperda yang disampaikan oleh gubernur atau bupati/walikota digunakan sebagai bahan untuk dipersandingkan. 
c. Pembahasan Raperda di DPRD.

Pembahasan Raperda di DPRD dilakukan oleh DPRD bersama gunernur atau bupati/walikota. Dalam pembahasan ini gubernur atau bupati/walikota dapat diwakilkan, kecuali dalam pengajuan dan pengambilan keputusan. Pembahasan bersama tersebut dilakukan melalui tingkat-tingkat pembicaraan yang dilakukan dalam rapat komisi/panitia/alat kelengkapan DPRD yang khusus menangani bidang l;egislasi dan rapat paripurna. Pada tahap pembahasan ini apabila DPRD atau gubernur atau bupati/ walikota akan menarik kembali Raperda yang diajukan, maka harus berdasarkan persetujuan bersama DPRD dan gubernur atau bupati/walikota.

\section{d. Penetapan.}

Raperda yang telah disetujui bersama oleh DPRD dan gubernur atau bupati/ walikota disampaikan oleh pimpinan DPRD kepada gubernur atau bupati/ walikota untuk ditetapkan menjadi Peraturan Daerah. Penyampaian Raperda tersebut dilakukan dalam jangga waktu paling lambat 7 (tujuh) hari terhitung sejak tanggal persetujuan bersama. Agar segera ada kepastian hukum, penetapan Raperda oleh gubernur atau bupati/walikota ditentukan paling lambat 30 (tiga puluh) hari sejak Raperda disetujui bersama oleh DPRD dan gubernur atau bupati/walikota. Berdasarkan ketentuan UU No. 12 Tahun 2011 dan UU No. 32 Tahun 2004 jo UU No. 12 Tahun 2008 tentang Pemerintahan Daerah, apabila Raperda tidak ditandatangani oleh gubernur atau bupati/ walikota dalam waktu paling lambat 30 (tiga puluh) hari sejak Raperda disetujui bersama maka Raperda tersebut sah menjadi Peraturan Daerah dan wajib diundangkan dengan memuatnya dalam Lembaran Daerah.

\section{e. Pengundangan dan Penyebarluasan.}

Peraturan daerah yang telah ditetapkan oleh Kepala Daerah agar memiliki kekuatan hukum dan mengikat masyarakat harus diundangkan dalam Lembaran Daerah yang pelaksanaannya dilakukan oleh Sekretaris Daerah. Dengan diundangkannya Peraturan Daerah dalam lembaran resmi (lembaran Daerah) maka setiap orang dianggap telah mengetahui.
2. Urgensi Naskah Akademik dan Peran Serta Masyarakat dalam Penyusunan Perda Dalam Rangka Tata Kelola Pemerintahan Yang Baik di Daerah.

Naskah Akademik merupakan Rancangan Pendahuluan untuk menyusun Draft Raperda dan merupakan hasil kesimpulan dari pekerjaan tim peneliti. Dapat dikatakan bahwa suatu Naskah Akademik sebagai kesimpulan dari laporan penelitian yang telah dilakukan beberapa lama dengan metode tertentu. Idealnya sebuah Laporan Penelitian haruslah memenuhi kaidah-kaidah tata tulis yang telah ditentukan. Dalam penyusunan Perda idealnya didahului dengan Naskah Akademik. Hasil penelitian di tiga lokasi penelitian ternyata tidak semua Perda didahului dengan Naskah Akademik. Untuk Perda Pegelolaan Lingkungan Hidup sudah didahului dengan Naskah Akademik, namun tidak semua Perda didahului dengan Naskah Akademik. Penyusunan Naskah Akademik ini mengacu pada Lampiran I UU No. 12 Tahun 2011. Bahwa Naskah Akademik merupakan bagian yang tidak dapat dipisahkan dari penyusunan sebuah Rancangan Undang-Undang termasuk Perda karena dimuat gagasan-gagasan pengaturan serta materi muatan perundangundangan bidang tertentu yang telah ditinjau secara sistematik holistik dan futuristik dari berbagai aspek ilmu. Bahwa Naskah Akademik juga merupakan bahan pertimbangan yang dipergunakan dalam permohonan izin prakarsa penyusunan Raperda kepada Gubernur.

Naskah Akademik adalah Naskah awal yang memuat gagasan-gagasan pengaturan dan materi muatan perundang-undangan bidang tertentu disebut Naskah Akademik Peraturan Perundang-undangan. Naskah Akademik memuat gagasan pengaturan suatu materi perundang-undangan (materi hukum) bidang tertentu yang telah ditinjau secaraholistik-futuristik dan dari berbagai aspek ilmu, dilengkapi dengan referensi yang memuat: urgensi, konsepsi, landasan, alas hukum dan prinsip-prinsip yang digunakan serta pemikiran tentang norma-norma yang telah dituangkan ke dalam bentuk uraian yang sistematis dan dapat dipertanggungjawabkan secara IImu Hukum dan sesuai dengan politik hukum yang telah digariskan.

Unsur-unsur yang perlu ada dalam suatu Naskah akademik adalah urgensi disusunnya pengaturan baru suatu materi hukum yang menggambarkan : 
1. Hasil inventarisasi hukum positif:

2. Hasil inventarisasi permasalahan hukum yang dihadapi;

3. Gagasan-gagasan tentang materi hukum yamg akan dituangkan ke dalam Rancangan Perda;

4. Konsepsi landasan, alas hukum dan prinsip yang akan digunakan;

5. Pemikiran tentang norma-normanya yang telah dituangkan ke dalam bentuk pasalpasal;

6. Gagasan awal naskah Rancangan Perda yang disusun secara sistematis : bab demi bab, serta pasal demi pasal untuk memudahkan dan mempercepat penggarapan Raperda selanjutnya oleh instansi yang berwenang menyusun Raperda tersebut.

Pertimbangan lain perlunya partisipasi masyarakat dalam penyelenggaraan pemerintahan adalah:

1. bahwa keterlibatan masyarakat merupakan unsur penting dalam membangun dan mengembangkan system pemerintahan yang aspiratif dan demokratis, mampu melayani kepentingan dan kebutuhan masyarakat dengan baik;

2. partisipasi sebagai salah satu prinsip pemerintahan yang baik (good governance) perlu dikembangkan dalam rangka mendorong warga masyarakat menggunakan pikiran dan pendapatnya dalam setiap pengambilan keputusan yang menyangkut kepentingannya, pelaksanaan dan evaluasi penyelenggaraan pemerintahan dan program pembangunan di daerahnya;

3. pelibatan masyarakat baik secara langsung maupun tidak langsung akan membangun kemitraan antara pemerintah dan masyarakat untuk bersama-sama bertanggungjawab terhadap keberhasilan penyelenggaraan pemerintahan dan pembangunan.

3. Kendala Yang Dihadapi Eksekutif dan Legislatif dalam Tahap Formulasi Kebijakan.

Bila melihat mekanisme pembuatan peraturan perundangan sebagaimana dijelaskan diatas maka tidak dapat dipungkiri terdapat banyak kendala dalam mekanisme penyusunan Perda yang selama ini dijalankan oleh Pemerintah Daerah.

a. Kendala yang pertama adalah keterbatasan masuknya peran serta masya- rakat dalam formulasi legal drafting Perda. Kendala tersebut sebenarnya telah dieliminir dengan Undang-Undang No.12 Tahun 2011 tentang Pembentukan Peraturan Perundang-Undangan. Dimana dalam Undang-Undang No.12 Tahun 2011, partisipasi masyarakat yang berupa masukan secara lisan dan tertulis sudah diberi kesempatan sejak saat penyiapan Raperda bahkan sampai pada tahap pembahasan. UU No. 12 Tahun 2011 memberikan kesempatan kepada stakeholders untuk membahas sejak awal persiapan mulai dari Naskah Akademis atau background paper dimana latar belakang, asas, cakupan tujuan dan sasaran Raperda masih diperdebatkan.

b. Belum adanya kebijakan perencanaan mengenai perlindungan dan pengelolaan lingkungan hidup yang menjadi payung dan pedoman bagi kebijakan secara makoro guna mengoptimalkan pengelolaan dan pelestarian sumber daya alam yang didasarkan pada prinsip kelestarian, demokrasi ekonomi, keterbukaan, kemakmuran rakyat, keadilan dan efesiensi yang berorientasi pada pembangunan berkelanjutan.

c. Keterbatasan dalam kemampuan menilai Perda yang sudah ada misalnya, harus secara konkrit mengisi pasal demi pasal dan bisa menjawab dengan jelas tiap pertanyaan mengenai apa yang ingin diatur dan apa targetnya.

\section{Simpulan}

1. Penyusunan pembentukan Peraturan Daerah yang dilakukan oleh Pemerintah Daerah (ekskutif dan DPRD) di Kabupaten Nganjuk belum optimal karena belum semua perda sesuai dengan UU No. 12 Tahun 2011 dan UU No 32 Tahun 2004 serta UU No. 32 Tahun 2009, sehingga belum semua Perda menggunakan Naskah Akademik dalam formulasi Legal Drafting Perdanya.

2. Dalam tahap pembentukan Legal Drafting Perda dalam rangka penyelenggaraan good governance peran serta masyarakat dalam penyusunan Naskah Akademik dan Raperda mutlak diperlukan. Hasil penelitian partisipasi belum berjalan efektif dan belum semua Perda didahului Naskah Akademik.

3. Kendala Yang Dihadapi Eksekutif dan Legislatif dalam Tahap Formulasi Kebijakan: Kendala yang pertama adalah keterbatasan masuknya peran serta masyarakat dalam pembentukan 
penyusunan Perda; Keterbatasan penyusunan rencana perlindungan dan pengelolaan lingkungan hidup, Belum adanya landasan yang kuat dalam Tatib DPRD agar dibuat sebuah Naskah Akademik terlebih dahulu dalam formulasi legal drafting Perda; Belum adanya kebijakan kajian lingkungan hidup strategis mengenai perlindungan dan pengelolaan lingkungan hidup yang menjadi payung dan pedoman bagi kebijakan secara makro guna mengoptimalkan pengelolaan dan pelestarian sumber daya alam yang didasarkan pada prinsip kelestarian, demokrasi ekonomi, keterbukaan, kemakmuran rakyat, keadilan dan efesiensi yang berorientasi pada pembangunan berkelanjutan; Keterbatasan dalam kemampuan menilai Perda yang sudah ada.

\section{E. Saran}

1. Perlu dilanjutkan penelitian untuk menyusun pedoman dan standar prosedur operasional, memberikan pelatihan, pendampingan serta monitoring bagi eksekutif (leading sector) dan anggota DPRD serta penekanan dalam rangka formulasi legal drafting yang dilakukan eksekutif dan DPRD agar menghasilkan perda yang berbasis lingkungan seperti yang diatur dalam UU No. 32 Tahun 2009.

2. Perlu dilakukan sosialisasi kontinyu mengenai pentingnya menumbuhkan kesadaran serta kepedulian terhadap lingkungan dan disusunnya Rencana Perlindungan dan Pengelolaan Lingkungan serta Kajian Lingkungan Hidup Strategis sebagai pedoman dalam pengambilan kebijakan.

3. Perlu pengaturan Naskah Akademik dalam formulasi legal drafting di dalam Perda.

4. Membuat satu kebijakan bagi masyarakat sipil supaya dapat berperan secara maksimal dalam mengontrol kebijakan daerah dalam pengelolaan sumber daya alam.

5. Perlunya kebijakan dalam penyusunan peraturan perundang-undangan berbasis lingkungan. 


\section{Daftar Pustaka}

Gunningham, N. and Grabosky, P. 1998. Smart Regulation, Designing Environmental Policy, Oxford, Clarendon Press.

I Gusti Ayu. 2005. Judicial Review Undang-Undang Nomor 7 Tahun 2004 Tentang Sumber Daya Air. Laporan Penelitian MKRI. Fakultas Hukum UNS : Surakarta.

I Gusti Ayu. 2006. Urgensi Pengelolaan SDA Pasca Putusan MKRI 2005. Laporan Penelitian MKRI. Fakultas Hukum UNS : Surakarta.

I Gusti Ayu. 2007 .Sinkronisai Perda Kota Surakarta no. 2 tahun 2006 tentang Pengendalian LH Terhadap UUPLH Laporan Penelitian DIPA FH UNS. Fakultas Hukum UNS : Surakarta. John Finnis, 2011. Human Rights \& Common Good, Oxford University Press.

Laurence C., Smith. 2011. The World in 2050 Four Forces Shaping Civilizations Northern Future, A Plume Book.

Lexy J. Moleong. 2005. Metodologi Penelitian Kualitatif. Bandung: P.T. Remaja Rosdakarya. Marzuki. 2002. Metodologi Riset. Yogyakarta: BPFE-UII.

Peter Mahmud Marzuki. 2006. Penelitian Hukum. Akarta: Kencana Prenada Media Group.

Steinzor, R.I. 1998. Reinventing Environmental Regulation: The Dangerous Journey From Command to Self- Control. Harvard Law Review. Vol. 22,

W. Gulo. 2002. Metodologi Penelitian. Jakarta: P.T. Gramedia Widiasarana Indonesia.

Undang-Undang Nomor 32 Tahun 2004 Jo. Undang-Undang Nomor 12 Tahun 2008 Tentang Pemerintahan Daerah.

Undang-Undang Nomor 32 Tahun 2009 Tentang Perlindungan dan Pengelolaan Lingkungan Hidup.

Undang-Undang Nomor 12 Tahun 2011 Tentang Pembentukan Peraturan Perundang-Undangan 